\title{
Ke konstituování hudební regionalistiky jako legitimní dílčí muzikologické disciplíny
}

\section{To Creation of Musical Regional Science as a Legitimate Partial Musical Discipline}

Karel Steinmetz / karel.steinmetz@osu.cz

Department of Music Education, Faculty of Education, University of Ostrava, Ostrava, CZ

\begin{abstract}
This article summarizes constitution of the musical regional science as a fully legitimate musicological discipline in the mid-1960s in the Czech Republic and abroad. This discipline has its own research objects and goals, as well as its history, but it uses research methods across the other musicological and other disciplines, and its application point is rather directed towards the field of study of local cultural and historical localities and smaller regional units.
\end{abstract}

\section{Keywords}

musical regional science, regionalism, disciplines of Musicology, Jiř́ Fukač

Tento příspěvek pod názvem Fukačův prínos ke konstituování hudební regionalistiky jako legitimni dil'či muzikologické disciplíny byl přednesen na konferenci Jiří Fukač inspirující, pořádané Ústavem hudební vědy Masarykovy univerzity v Brně 16. listopadu 2016. 
Otázku, zda je hudební regionalistika samostatnou dílčí muzikologickou disciplínou či je součástí spíše hudební historiografie, hudební sociologie, hudební folkloristiky či třeba i organologie apod. si kladli zhruba od poloviny 60. let minulého století mnozí muzikologové. Například Jiří Fukač ještě ve skriptu $O$ studiu hudebni vědy ${ }^{1}$ nemá o hudební regionalistice ani zmínku, ale už od vyškovského kolokvia o významu regionální kultury, ${ }^{2}$ a pak v nově vzniklém časopisu Opus musicum, v němž založil rubriku Kapitoly z hudební topografie, ${ }^{3}$ a zvláště v přínosné stati k základním otázkám hudební regionalistiky Hudba a člověk v prostoru, ${ }^{4}$ promýšlel tehdy mladý český muzikolog základní otázky problematiky tohoto oboru. Pak dal také podnět ke vzniku konferencí Muzikologické dialogy, které ve druhé polovině sedmdesátých let a v letech osmdesátých minulého století pořádala Česká hudební společnost ve spolupráci s brněnskou muzikologickou katedrou i dalšími organizacemi. Na těchto sympóziích přednesl dva pozoruhodné konferenční příspěvky, a to v roce $1976 \mathrm{v}$ Benátkách nad Jizerou: K základním pojmům a úkolům hudební regionalistiky ${ }^{5}$ a o dva roky později v Zákupech: Severní Čechy jako problém hudební regionalistiky; ${ }^{6}$ předtím v Brně na konferenci Morava v české hudbě měl Fukač podobný příspěvek, ale to bylo o Moravě jako typu hudebního regionu. ${ }^{7}$ Po roce 1989 , ve změněných kulturně politických podmínkách, na XX. Mikulovském sympoziu mluvil Fukač velmi otevřeně o ideologických nánosech, které ovlivnily regionalistiku u nás v předcházející době v příspěvku Otázky regionu a mezinárodních vztahů. ${ }^{8}$ Fukačovo uvažování o problematice hudební regionalistiky pak vyústilo do textu hesla „hudebni regionalistika“ napsaného ve spoluautorství s Josefem Válkou pro Slovnik české hudebni kultury. ${ }^{9}$ Zcela poslední hudebněregionalistický příspěvek měl Jiří Fukač na konferenci v rámci greifswaldských hudebních dnů v roce $1992,{ }^{10}$ nepočítáme-li příspěvky s podobnou, ale poněkud širší tematikou. ${ }^{11}$

1 FUKAČ, Jiří. O studiu hudebni vědy. 1. vyd. Praha: Státní pedagogické nakladatelství, 1964.

2 Na tomto kolokviu přednesl Jiří Fukač referát s názvem Hudební regionalistika a její vztah k hudebněsociologickému bádání. Zprávy Muzea Vyškovska č. 78, září 1969, s. 11-16.

3 Zde např. publikoval článek Znojemské Hradiště. Opus musicum, 1970, roč. 2, č. 7, s. 214-215.

4 FUKAČ, Jiří. Hudba a člověk v prostoru (K základním otázkám hudební regionalistiky). Opus musicum, 1970 , roč. 2, č. 5-6, s. 129-135.

5 FUKAČ, Jiří. K základním pojmům a úkolům hudební regionalistiky. In Čechy rezervoár hudebnosti. Mladá Boleslav: Okresní kulturní středisko, 1978, s. 99-115.

6 FUKAČ, J. Severní Čechy jako problém hudební regionalistiky. In Muzikologické dialogy 1978. Brno: Jihomoravská odbočka České hudební společnosti, 1980, s. 13-18.

7 FUKAČ, J. Morava jako typ hudebního regionu. In Morava v české hudbě. Brno: Svaz českých skladatelů a koncertních umělců, 1985, s. 14-17.

8 FUKAČ, J. Otázky regionu a mezinárodních vztahů. In Kulturně historické styky jižni Moravy. XX. Mikulovské sympozium 24.-25. ř́jna 1990 (Mikulov-Brno 1991, s. 5-14).

9 Slovnik české hudebni kultury. Jiří Fukač - Jiří Vysloužil - Petr Macek (eds.). 1. vyd. Praha: Editio Supraphon, 1997, s. 329-330.

10 FUKAČ, Jiří. Das Regionale als Gegenstand der Musikforschung. In Zu interregionalen musikkulturellen Beziehungen im Ostseeraum, Greifswald: 1993, s. 5-19.

11 Např́iklad Fukačův příspěvek na konferenci Musikkultur in Schlesien zur Zeit von Telemann und Dittersdorf Schlesische Impulse in der Musikgeschichte der böhmischen Länder v Pszczyně v roce 1993. 
Ve slovníkovém hesle je hudební regionalistika charakterizovaná jako věda, která se zaměřuje na specializovaný výzkum hudebního dění v přesně vymezených topograficko-regionálních souvislostech. $\mathrm{V}$ hesle je vysvětlen rozdíl mezi výrazy regionalistika a regionalismus: „Regionalismus se chápe jako hnutí usilujici o zachováni krajové svébytnosti a o povzneseni či poznáni určitého krajového celku [...], kdežto regionalistika jako vědecký výzkum obracejici se $k$ problematice regionu jako $k$ svému předmětu může existovat i nezávisle na regionalismu, zvl. na lokálně patriotických zájmech a motivacích. "12 Na jiném místě ještě Jiřri Fukač dodává: „Tedy regionalistické vědecké bádáni se musi odtrhnout od často nekritického vlastivědného, z obrozeneckého pohledu vycházejicího a vedouciho spiše $k$ lásce $k$ vlasti“ ${ }^{13}$

Fukačovy názory na hudební regionalistiku, které publikoval v těchto statích, se ted' pokusíme systematicky uspořádat. Vycházel z toho, co o regionalismu a regionalistice napsali třeba J. F. Fischer, J. Bartoš, Z. Nejedlý i badatelé obecné historie (zde připomeňme, že hlavním zakladatelem regionalistiky - tedy sociálněvědní disciplíny, zabývající se studiem prostorových jevů, procesů a vztahů, byl v 50. letech minulého století americký ekonom Walter Isard (1919-2010)); Fukač však byl prvním, kdo hovořil (nejen v českém kontextu) přímo o vědecké hudební regionalistice. Hned ve svých prvních statích o této problematice píše: „Jde nám o ustaveni hudebni regionalistiky jako skutečného vědního oboru [...]“, nebot dosud se „hudebni regionalistika nevymanila z pragmatického vlastivèdného pojetí. [...] Skutečně vědecká hudebni regionalistika musí být v prvé radě zbavena jakéhokoliv nacionalistického (či jinak ideologizujicího) partikularismu. $Z$ dějin regionu nemůžeme vyškrtnout činnost mimočeských skupin obyvatelstva, produkci vykořistovatelských tř́d a religiózni sféru jen proto, že my sami jsme Češi, marxisté a ateisté. [...] Vědecká hudebni regionalistika mũže být námětově vázána $k$ provinčni tematice. To v̌̌ak neznamená, že by směla být provinčni. " ${ }^{14}$ Hudební regionalistice tedy autor vymezuje pevné místo samostatné disciplíny v hudební vědě, byt ji charakterizuje jako „metodicky nejzaostalejši obor muzikologie ${ }^{\text {“ }}{ }^{5}$ a proto je prý nutné propracovat právě metodologii této disciplíny. Tak si např́íklad všímá třeba metodologických důsledků v rozdílu mezi chápáním mimohudebního (vymezeného třeba hranicemi politickosprávních celků) a hudebního regionu. Ve studii Hudba a člověk v prostoru (K základním otázkám hudební regionalistiky) ovšem píše: „Neznáme ani dobrou definici hudebního regionu, mistopisných jednotek, na nĕž se váže hudebni vývoj, hudebni lokality, centra, terénu atp. " ${ }^{16}$ A tak v dalších podkapitolkách této studie (nazvaných Region - plocha nebo prostor, Hudba není jen zvuk i Hledání dalších pojmů) se pokouší precizovat základní terminologické uchopení vědecké hudební regionalistiky a vymezuje pojmy jako „hudební region“ a širrení hudby v něm (zde např. vidí rozdíl mezi „hudbou v regionu“ a „hudebním regionem“), „hudební lokalita“, vztah mezi regionem a hudebním centrem atd. Hudební regionalistika si musí najít „speciální zájmový resort“ nepokrytý péčí jiných oborů.

12 FUKAČ, J. - VYSLOUŽIL. J. - MACEK, P., op. cit., s. 329-330.

13 FUKAČ, J., 1969, op. cit., s. 16.

14 FUKAČ, J., 1969, op. cit., s. 11.

15 FUKAČ, J., 1970b, op. cit., s. 129.

16 Ibid., s. 129. 
Ve studii K základním pojmům a úkolům hudební regionalistiky podává návrh, jak co nejorganičtěji začlenít výzkum hudebněregionalistických skutečností do hudebně vědné systematiky. Poznání dané jevové oblasti postupovalo ve třech vzájemně nekoordinovaných směrech:

1. směr: Studiem provenienčního hlediska, tedy místa původu hudebních aktivit, produktů a tvaroslovných prostředků, jako jsou např. frygická stupnice, neapolský sextakord, benátská opera, vídeňská škola či třeba moravská hudba (zde je nutné ovšem správně rozpoznat vztah hudby $\mathrm{k}$ regionu - ten může podle Fukače být redukovaně nazírán jako pouhé genetické zakotvení daných jevů v tom kterém geografickém prostředí a stranou zůstávají momenty jako fungování či migrace.

2. směr: Zkoumání výskytu hudebních jevů v geografických celcích či topografických jednotkách je ovšem postaveno na lokálně patrioticky motivovaném sběru faktů a tím, že vlastivědně orientovaní badatelé chápou regiony př́liš staticky, často jako místo třeba státní správy, bez ohledu na jeho dějinnou proměnlivost.

3. směr: Třeba při vymezování hudebního regionu se upozorňuje na to, že v minulosti (ale i dnes, kdy vše komplikují masové komunikační prostředky - rozhlas, televize, my dodáváme internet a jiné šíření hudebních nahrávek - LP, CD apod.) každý druh a žánr hudby by mohl mít jinak vymezené hranice regionu (jinak u lidové písně, jinak u dechovky či koncertní vážné hudby, rocku apod.). V tom mají velké zkušenosti při výzkumu v terénu zvláště hudební folkloristé, hovořící o etnografické diferenciaci a jednotlivých etnografických rajónech.

Prvním úkolem hudební regionalistiky je - podle Jiřího Fukače - osvětlení terénu, v němž se hudba uplatňuje ,jako konkrétni trojrozměrný terénni prostor, zaplněný rozmanitými objekty, v němž lidé provozuji své hudebni aktivity produkčni, reprodukční, receptivni a komunikativni povahy. $V$ tomto prostoru se nacházeji nesčetné dilči prostorové celky, v nichž docházi k provozováni hudby, tedy prenosu hudebni informace od producenta ke konzumentovi. "17 Fukač má na mysli různé sály, divadla, kostely, hudba může zaznívat i v plenéru, na ulicích, na lodích (zde připomíná musicu navalis, ale třeba i hudbu na záoceánských parnících či lodích plujících po Mississippi - riverboats), dále třeba migraci: cestovní trasy operních společností a dalších hudebníků aj. Myšlenka, že hudba není jen zvuk, souvisí se šířením „zvukových konzerv“, hudebnin, autografů či opisů skladeb, vzpomenuté migrace osob (at̉ už skladatelů, interpretů a zároveň hudebních pedagogů, výrobců nástrojů či kritiků, hudebních spisovatelů apod. - zde např. připomeňme Burneyův hudební cestopis apod.). Hudební regiony - tedy regiony, v nichž hudba „žije“ - jsou ale velmi labilní a podléhají přirozeným historickým tlakům, přestože nejsou vždy totožné s hranicemi států, politickosprávními reformami či válkami apod. Fukač zde např. upozorňuje na skutečnost, že hudební region má smysl jedině ve spojení s určitým druhem hudby, jak bylo připomenuto výše; univerzální hudební regiony vlastně neexistují.

U toho, jak je určitý komplexní či dílčí hudební jev rozprostraněn v terénu, můžeme abstrahovat do jisté míry od času a uvažovat o prostorovém rozšíření fenoménu vzhledem $\mathrm{k}$,časovému průřezu“.

17 FUKAČ, 1970, op. cit., s. 130. 
Potud interpretace Fukačových názorů na hudební regionalistiku. Všimněme si však určitého posunu v jeho uvažování, ${ }^{18}$ který nastal již v roce 1976 , kdy ve svém referátu na sympoziu v Benátkách nad Jizerou Čechy - rezervoár hudebnosti, publikovaném o dva roky později ve sborníku vydaném Okresním kulturním střediskem v Mladé Boleslavi, napsal:

„Autor této studie [tedy Jiří Fukač - pozn. KS] se dřive klonil k názoru, že by bylo účelné konstituovat hudebni regionalistiku jako novou samostatnou disciplinu hudebni vědy. Sled uvedených hudebně regionalistických pojmů totiž koneckonců vymezuje určitou kompaktni objektovou sféru, která by se mohla stát dostatečně nosným předmětným polem autonomního vědního oboru. Bez diskuse by byl $i$ cil a účl takové discipliny. Problémy však začinaji tam, kde bychom se pokoušeli o vytvořeni integrované oborové metodologické báze [zvýraznil KS]. K dispozici je až přiliš mnoho rüznorodých, $v$ rozmanitých disciplinárnich kontextech vyvinutých metod a pro ty výklad zásadnich otázek bude třeba zvolit zcela nové postupy, jejichž varieta by nebyla o nic menši. Nový obor by se tak stal značně nesourodým konglomerátem pracounich technik a metod, což by vždy znovu problematizovalo a oslabovalo integritu discipliny, jejiž začleněni do systematiky muzikologie by se ostatně neobešlo bez značných obtiži. To nás dnes vede k přesvědčeni, že zaváděni nových oborů, zmnožujicich a komplikujicich systém věd a kopirujicich tradični pozitivistické vzorce vědnich oborů neni ani zdaleka optimálni cesta rozvoje soudobého vědního poznáni. [...] Vnitřni pohyb vědy i tlak vnějši praxe vede k jiným modeli̛m výzkumné práce. "19

Na tomto místě Fukač navrhuje další alternativu - interdisciplinární symbiózu s jinými obory, jakými jsou hudební historiografie provádějící základní výzkum diachronního pohybu hudby lidskými dějinami, hudební sociologie studující vzájemný vztah lidských pospolitostí a jevů hudební kultury, etnomuzikologie specifikující vztah hudby k etnickým pospolitostem a v mnohém doplňující nedostatečná hudebněhistorická řešení, hudební antropologie pokoušející se o vypracování typologie hudebních entit vzhledem k základním kvalitám lidského subjektu, hudební akustika zkoumající některé význačné relace hudby v prostoru, geografie atp. „Pro vědecké vysvětleni vztahu hudby a regionu jsou relevantni $i$ aspekty sledované vědami, jež stoji mimo systém současné muzikologie a predmětně $i$ metodologicky přesahuji jeji gnoseologický kontext. Proto by měl být zformován svébytný výzkumný resort [zvýraznil KS] mnohdy bez ohledu na tradični disciplinárni hranice. Tento resort by pak neměl být koncipován podle pozitivistických disciplín: jeho strukturace by měla obrazně rečeno probihat např́í tradičním disciplinárním systémem muzikologie $i$ dalšich relevantnich oborů. Jádrem by se stalo řšeni obecných problémů vztahu hudby a regionu chápaného jako konkrétni historicko-kulturni forma prostoru, tematický rozsah výzkumu by pak byl dán napojenim na účinně koordinované interdisciplinárni bádání podnikané ve výše uvedených oborech. Resort by primárně reprezentoval rovinu základního muzikologického výzkumu, avšak jeho aplikačni vyústěni by směrovalo do sfér pokrývaných dosud vlastivědným studiem a kulturně historickým průzkumem terénu. " 20 Tedy vědeckou hudební regionalistiku chápe Fukač jako svébytný

18 Srov. BAJGAROVÁ, Jitka. Hudební regionalistika v brněnské muzikologické škole. In Musicologia Brunensis. Ad honorem Jan Racek, Bohumir Štědroñ et Zdeněk Blažek 1905-2005. Praha: Koniasch Latin Press, 2005, s. 226.

19 FUKAČ J., 1978, op. cit., s. 108.

20 Ibid., s. 109. 
výzkumný resort (jako interdisciplinární symbiózu s jinými obory), resort, který má svůj předmět bádání, výzkumné cíle, event. i svoji historii, ale své výzkumné metody používá napříč ostatními muzikologickými i dalšími vědními obory, jenž sice reprezentuje základní muzikologický výzkum, ale jeho aplikační vyústění zatím směřuje do oblastí vlastivědného studia místních kulturně historických lokalit a menších regionálních celků.

\section{Bibliography}

FISCHER, J. Ludvík. Kultura a regionalismus. 1. vyd. Brno: Index, 1930.

FRIC, Ota. K českému hudebnímu místopisu. In Hudba a národ. Praha: Svaz českých knihkupců a nakladatelů, 1940, s. 151-153.

NEJEDLÝ, Zdeněk. O novém regionalismu. Var, 1949, roč. 2, č. 1, s. 1-13.

RACEK, Jan Česká hudba a regionalismus. In Sbornik praci Filozofické fakulty brněnské univerzity, Řada hudebněvědná, 19, 1970, H 5, s. 7-20.

FUKAČ, Jiří. O studiu hudebni vědy. 1. vyd. Praha: Státní pedagogické nakladatelství, 1964.

FUKAČ, Jiří. Hudební regionalistika a její vztah k hudebněsociologickému bádání. Zprávy Muzea Vyškovska č. 78, září 1969, s. 11-16.

FUKAČ, Jiří. Znojemské Hradiště. Opus musicum, 1970, roč. 2, č. 7, s. 214-215.

FUKAČ, Jiří. Hudba a člověk v prostoru (K základním otázkám hudební regionalistiky). Opus musicum, 1970, roč. 2, č. 5-6, s. 129-135.

FUKAČ, Jiří. K základním pojmům a úkolům hudební regionalistiky. In Čechy rezervoár hudebnosti. Mladá Boleslav: Okresní kulturní středisko, 1976, s. 99-115.

FUKAČ, J. Severní Čechy jako problém hudební regionalistiky. In Muzikologické dialogy 1978. Brno: Jihomoravská odbočka České hudební společnosti, 1980, s. 13-18.

FUKAČ, J. Morava jako typ hudebního regionu. In Morava v české hudbě. Brno: Svaz českých skladatelů a koncertních umělců, 1985, s. 14-17.

FUKAČ, J. Otázky regionu a mezinárodních vztahů. In Kulturně historické styky jižní Moravy. XX. Mikulovské sympozium 24.-25. ř́jna 1990, Mikulov-Brno: 1991, s. 5-14.

Slovnik české hudebni kultury. Jiří Fukač - Jiří Vysloužil - Petr Macek (eds.). Praha: Editio Supraphon, 1997.

FUKAČ, Jiří. Das Regionale als Gegenstand der Musikforschung. In Zu interregionalen musikkulturellen Beziehungen im Ostseeraum, Greifswald: 1993, s. 5-19.

BAJGAROVÁ, Jitka. Hudební regionalistika v brněnské muzikologické škole. In Musicologia Brunensis. Ad honorem Jan Racek, Bohumir Štědroň et Zdeněk Blažek 1905-2005. Praha: Koniasch Latin Press, 2005, s. 224-230.

STEINMETZ, Karel. Od vlastivědy k vlastní vědě. O historii a současnosti hudebně regionalistického bádání, zvl. na Moravě a ve Slezsku. Musicologica Brunensia, 2009, roč. 44, č. 1, s. 181-190. 